\title{
Effects of terrains' soil and altitude on performance of Abyssinian pea (Pisum sativum var. abyssinicum A. Braun) landraces of Ethiopia
}

\author{
BERHANU ABRAHA TSEGAY ${ }^{1, *}$, BERHANE GEBRESLASSIE GEBREEGZIABHER ${ }^{1,2, *, *}$ \\ ${ }^{1}$ Department of Biology, College of Sciences, Bahir Dar University, P.O.Box 76, Bahir Dar, Ethiopia \\ ${ }^{2}$ Department of Biology, Faculty of Natural and Computational Sciences, Wodia University. P.O.Box 400, Woldia, Ethiopia. ^email: birie2006@gmail.com \\ *Authors have equal contribution
}

Manuscript received: 19 September 2019. Revision accepted: 4 November 2019.

\begin{abstract}
Tsegay BA, Gebreegziabher BG. 2019. Effects of terrains' soil and altitude on performance of Abyssinian pea (Pisum sativum var. abyssinicum A.Braun) landraces of Ethiopia. Biodiversitas 20: 3467-3477. Pea production in Ethiopia is mainly located in the highlands. Field-based agronomic performance evaluation of Abyssinian pea landraces at different altitudes and soil types are rarely explored. This study was conducted to assess the effects of soil composition and altitude on morphological and yield traits of three landraces. The experimental investigation used was a completely randomized block design. Morphological and yield traits of the landraces considered in this study varied across agroecology. The variations were due to soil nutrient differences, altitude of the agroecology and their interactions. Soil samples collected from the mid-altitude had the highest $\mathrm{pH}$ of $7.71 \pm 0.07$. Cation exchange capacity of this soil was found to be $45.46 \pm 0.71$, in covenant with the approximate cation exchange capacity of most soils (>40 CEC $\mathrm{meq} / 100 \mathrm{~g}$ soil) around neutral $\mathrm{pH}$. This agroecology was found to be best for overall performance of the landraces. In the highland terrain, the landraces were less vigorous and shorter in height. In the lowland terrain, landraces were taller in height but gave low yield. Gedober 2017 landrace performed best in seed yield $(6.00 \pm 0.11 \mathrm{~g} / \mathrm{plant})$ and harvest index $(0.32 \pm 0.43)$ at the mid-altitude. From this study, farmers are mindful to cultivate Gedober 2017 landrace at midland and highland pea production potential areas of Ethiopia.
\end{abstract}

Keywords: Agroecology, Gedober 2017, morphological traits, terrain, yield traits

Abbreviations: AOAC: Association of Official Agricultural Chemists; CBD: Convention on Biological Diversity; CIAT: The International Center for Tropical Agriculture; CSA: Central Statistical Agency; FAO: Food and Agricultural Organization; IUSS: International Union of Soil Sciences; WRB: World Reference Base for Soil Resources; MoANR: Ministry of Agriculture and Natural Resources; NCR: North Central Region; UPOV-BMT: International Union for the Protection of New Varieties of Plants working group on Biochemical and Molecular Techniques;

\section{INTRODUCTION}

Peas play critical role in human nourishment (Snapp et al. 2018). The production needs to be increased by $2 \%$ to meet the sustainable basis of food and nutritional security demand by the year 2030 (Pal et al. 2009). Information about which legume crop grows and where in global agroecosystems is lucking. The numbers of original pea landraces from Africa are mainly Ethiopia and their optimum cultivation conditions have not been documented (Smýkal et al. 2013). Field pea currently ranks fourth among the pulses in the world with cultivated areas of 6.33 million hectares (FAO 2012). The crop is known to grow in Ethiopia since antiquity (Vavilov 1951; Difalco and Chavas 2009). Ethiopia is the chief producer of cool-season food legume crops in Africa (Meles et al. 2009; Gebreslassie and Abraha 2016; Agegnehu 2018). Field pea ranks fourth in Ethiopia in terms of both area coverage and total national production (CSA 2013).

Two Pisum botanical cultivars viz. P. sativum var. sativum and $P$. sativum var. abyssinicum are grown in Ethiopia. Their production is limited to subsistence farmers at small scale fields mainly located in the highlands (Meles et al. 2009; Agegnehu 2018, Gebreegziabher and Tsegay
2018). P. sativum var. abyssinicum is cultivated traditionally on poor soils that are not conducive to staple crops (CBD 2009). Nevertheless, there is no field-scale experiment work done with different terrains apart from the garden trial to discover Abyssinian peas from the John Innes Centre's seed bank. The garden trial was conducted with two different varieties from Ethiopia (https: //hodmedods.co.uk/blogs/news/abyssinian-peas). At $e x$ situ, Abyssinian pea was first grown in 1840 in the Botanic Garden at Karlsruhe-Baden by Alexander Braun from seeds sent by Wilhelm Schimper from Abyssinia (Hedrick 1928). The crop can grow both on midland altitude to highland altitude terrains (Gebreegziabher and Tsegay 2017, 2018). It can also grow in the low land terrains (Gebreegziabher and Tsegay 2017) as low as Gedober (at elevation of 1329 m. a. s. 1) and Chercher (at elevation of 1720 m. a. s. 1). As P. sativum var. abyssinicum is a crop that matures within about 75-90 days, it is usually weeded once or twice before it produces tendrils and flowers (MoANR 2016; Gebreegziabher and Tsegay 2018).

Botanically, $P$. sativum var. abyssinicum is a climbing, short, slender annual cool-season food legume. It has one pair of leaflets, corolla approximately $15 \mathrm{~cm}$ long and reddish-purple flower. The crop is a world crop protection 
and breeder agent's priority crop of gene interest (Mikić et al. 2013). It was collected and preserved starting from 1974 August to 2017 March and hitherto not complete in the world databases (https://www.gbif.org/ and http: //www.ville-ge.ch/musinfo/bd/cjb/africa) with inconsistent scientific names. This signifies necessity of a forerunner study on the crop's geographical location and soil-based agronomic characterization from the current cultivation terrains.

Pea producing farmers in Ethiopia are vulnerable to agricultural challenges due to climate change and variability (CIAT 2017). Though Ethiopia research centers are stated as responsible and aimed for undertaking research in various agroecologies (http://www.eiar.gov.et/ index.php/en/research/research-centers), there is no agroecological based study conducted so far for Abyssinian pea. This study was conducted based on agro-ecology to evaluate the effects of growing terrains soil and their altitudinal differences on the morphological and yield traits of three Abyssinian pea landraces.

The majority of varieties grown in Ethiopia are landraces, which exhibit significant genetic heterogeneity (Difalco and Chavas 2009). Besides, landraces diversity has greater beneficial value at degraded lands of Ethiopia. The terms terrain/terrains are thoroughly used in this paper to mean the growing lands used as field experiments for the Abyssinian pea landraces. Likewise, the authors used the term landrace/landraces after a farm or a locality for the Abyssinian pea farmers' seed varieties adapted to local growing conditions naturally with no intentional selection as per the definition reviewed by Berg (2009).

\section{MATERIALS AND METHODS}

\section{Description of the experimental terrains, materials, and experimental setups}

Field trial was carried out to evaluate three Abyssinian pea landraces collected from three different districts having different agroecology and altitudinal gradients in Northeast Ethiopia (Figure 1; Table 1). The districts and kebeles were selected after the pilot survey of 6 districts and 18 kebeles by the authors of this study (Gebreegziabher and Tsegay 2018). The fields were used for Teff production in 2017, after which it was used for the present study. Seed bedded soil preparation was carried out to ensure good seed-soil contact there by encouraging better stand establishment. Based on the common local farmers sowing time the three of the landraces were hand sown at three different locations and three different sowing dates. Three of the landraces were sown at Gedober lowland on 16 June 2017, at Sirinka midland on 24 June 2017, and at Wemberet highland on 23 August 2017. Hundred viable seeds were sown per meter square following the seeding rate of Abyssinian pea and method used by Mikić et al. (2013). The seeds were sown by hand in $2 \times 4 \mathrm{~m}$ plots with spacing between plants and rows of 10 and $30 \mathrm{~cm}$, respectively in a planting depth of 4 $\mathrm{cm}$. This was done with three replications on-farm under rainfall conditions. The landraces were sown without fertilizer application and weed management was done once before the landraces produce tendrils and flowers.
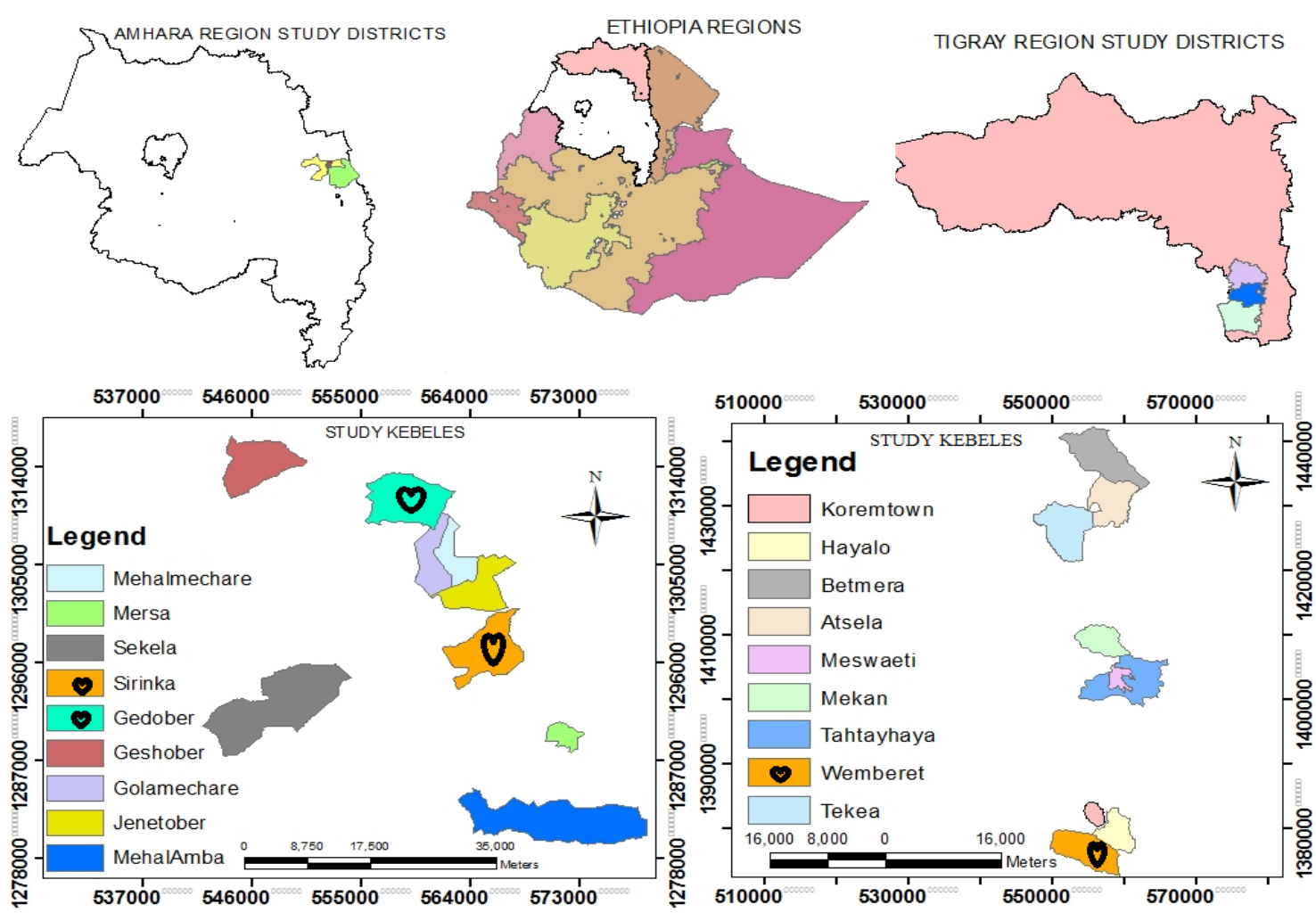

Figure 1. Map of Ethiopia showing locations of the study terrains labeled as kebeles within Amhara and Tigray regional states. Study terrains are specifically indicated by the heart shape $(\boldsymbol{\vee})$ on the map and their legends. 
Table 1. Experimental setup of the studied landraces and the study terrains

\begin{tabular}{lllllc}
\hline Landraces & Seed source district & Trial district & Trail kebele & Agroecology $^{\mathbf{a}}$ & Altitude $^{\mathbf{a}}$ \\
\hline Sirinka 2017 & Habru & Gubalafto & Gedober & Lowland & 1379 \\
Sirinka 2017 & Habru & Habru & Sirinka & Midland & 1868 \\
Sirinka 2017 & Habru & Ofla & Wemberet & Highland & 2457 \\
Gedober 2017 & Gubalafto & Habru & Sirinka & Midland & 1868 \\
Gedober 2017 & Gubalafto & Gubalafto & Gedober & Lowland & 1379 \\
Gedober 2017 & Gubalafto & Ofla & Wemberet & Highland & 2457 \\
Wemberet 2017 & Ofla & Ofla & Wemberet & Highland & Lowland \\
Wemberet 2017 & Ofla & Gubalafto & Gedober & Midland & 1379 \\
Wemberet 2017 & Ofla & Habru & Sirinka & .
\end{tabular}

Note: Kebele is small administrative unit of a district. Agroecology and altitudes are for cultivation trail districts

Completely randomized block design was used where the whole experimental fields of the three terrains were divided into blocks of homogeneous units based on soil type and landraces. This is to increase homogeneity within blocks with respect to soil type and landraces so as to reduce the error sum of squares in the analysis of variance. A combined analysis of experiments was carried out by repeating the same experiment at the three different research terrains (Table 1). This helps to know whether there is any interaction between terrains and landraces. Therefore, the study investigated soil characterizations and agronomic performances, and productivity of Abyssinian pea $(P$. sativum var. abyssinicum) in three different agroecological terrains.

\section{Soil sample collection and processing}

Composite soil samples representing the whole plots were taken in a zigzag pattern following the methods by Hue et al. (1997, 2004) and Thom et al. (2003). Clean utensils were used to collect soils. Plots were divided into their respective grid cells. Each composite contains 10 cores and each terrain was divided into 2.5-acre grid cells. Then, each cell was treated as an individual plot, and 10 random cores were taken from each cell following the common method of Anderson country cooperative extension for agricultural soil testing (Thom et al. 2003). Soils were dug at a depth of $15 \mathrm{~cm}$ after removing surface litter and the top $1.0 \mathrm{~cm}$ soil using auger. When the soil was sufficient air dried, it was passed through a $2 \mathrm{~mm}$ mesh sieve. Otherwise, the soil was removed to a cool, shady place to air dry until it can pass through the sieve (IUSS Working Group WRB 2015).

\section{Soil physicochemical content analysis}

Before sowing the landraces, representative field soil samples were sent to testing laboratory (Amhara Design and Supervision Works Enterprise and Laboratory Service) for analyses based on the outlined standard lab-based soil test protocols for agricultural soils (NCR-13 2011; Sharma 2019). The physicochemical contents of the soils were examined to learn about the specific nutrient contents. This is irrespective of the management practices, implement technologies, application of input level, timing of application, and date of sowing by the farmers in the different agro-ecologies.
Soil $\mathrm{pH}$ was measured in water and $1 \mathrm{M} \mathrm{KCl}$ in soil to solution ratio of 1: $5\left(\mathrm{pH}\left(\mathrm{H}_{2} \mathrm{O}\right), \mathrm{pH}(\mathrm{KCl})\right)$ using the glass electrode method. Determination of N, P, and K of the soils where the landraces were grown was carried out for the 10 core samples. Nitrogen concentration was determined by micro-Kjeldahl method ( $\mathrm{N} \times 6.25)$ according to AOAC (1960). Available phosphorus was estimated calorimetrically using Olsen et al. (1954) which is the recommended method to soils that are marginally acid to neutral and alkaline $\mathrm{pH}$. Potassium was determined using the flame emission spectrophotometer (AOAC 1960).

\section{Morphological and yield data collection methods}

Plants in a $1 \mathrm{~m}^{2}$ subplot at the center of each plot (which was left untouched until final harvest) were used for recording morphological and yield traits. Data for the agronomic performances and yield components were collected from sample plants for each landrace randomly selected from the $1 \mathrm{~m}^{2}$ subplot for each terrain. The selected plants were marked and data on individual plants was recorded for the characters except for days to 50 percent flowering and days to maturity. The plant height was measured in centimeters from the ground level to tip of the main stem at the time of harvest. To measure number of tillers per plant, the total numbers of branches directly arising from main stem of a plant were counted at physiological maturity stage. For days to $50 \%$ flowering, days taken from the date of sowing to the initiation of flowering were counted. The number of days from sowing to the complete pod maturity of the plants (pods turned dark golden brown to yellow-green) was used as a measurement for days to maturity. Ten pods randomly taken from the total pods of sampled plants and the seeds were counted and averaged per plant for number of seeds per plant. Total number of fully matured pods obtained from each plant were counted and averaged to obtain number of pods/plants. All the mature pods obtained from 10 previously selected and tagged plants were sun-dried to less than $12 \%$ moisture content and weighed on a top pan electric balance and the averages were taken to record seed yield per plant in grams. From the harvest of each plot, 1000 seeds were taken randomly and weighed in grams using electronic single pan balance for test weight in grams. Five randomly selected plants from each plot were harvested at maturity for seed count. These plants were 
sun-dried and weighed (including pods, excluding roots) and averaged to obtain biological yield per plant in grams. Finally, harvest index was calculated as the ratio of seed yield to biological yield expressed in percentage using the formula given by Donald (1962):

$$
\text { Harvest index }(\%)=\frac{\text { Seed yield } / \text { plant }(\mathrm{g})}{\text { Biological yield } / \text { plant }(\mathrm{g})} \times 100
$$

\section{Data analysis}

All data of soil samples were expressed on oven-dried basis. Univariate ANOVA using SPSS Software version 25 was employed to analyze the data. This was for the evaluation of the landraces growth performance responses and soil physicochemical contents of the study terrains. Mean comparison was done using Tukey Test at $\mathrm{P}<0.05$ as a test of significance level.

\section{RESULTS AND DISCUSSION}

\section{Soil properties of the study terrains}

Soil texture classes varied from clay for the midland to loam and clay loam for the highland and midland terrains, respectively (Table 2). ANOVA results showed that the exchangeable bases of the soils varied significantly at $\mathrm{P}<0.05$ (Table 2) with the exception of exchangeable sodium. Soil samples collected from the midland altitude (Sirinka) had $\mathrm{pH}$ of $7.71 \pm 0.07$. Clay loam soil samples from the lowland altitude (Gedeber terrain) have

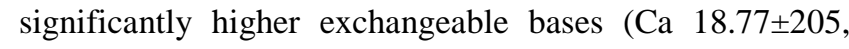
$\mathrm{Mg} \quad 4.90 \pm 0.30$ and $\mathrm{K} 0.26 \pm 0.03)$ than the highland agroecology. The midland soils have higher $\mathrm{K}$ level than the lowland but lower $\mathrm{Ca}$ and $\mathrm{Mg}$ levels. The variations were significant at $\mathrm{P}<0.005$ (Table 2). The exchangeable sodium content of the soil samples from the different terrains was not statistically significant at $\mathrm{P}<0.05$ (Table 2).

There was no statistically significant difference among the soil samples collected for available phosphorus, cation exchange capacity, organic matter, soil carbon content, and total nitrogen (Table 2). The exchange acidity varied among the growing terrains. The micronutrient contents of the soil samples were statistically significant only for iron. There was a statistically significant difference among the soil samples of different terrains on-field capacity and permanent wilting points (Table 2). The available phosphorus (P), organic matter (OM) and soil carbon content (SCC) were found to be higher on the lowland terrain although not statistically significant. The cation exchange capacity (CEC) was higher on the midland and total nitrogen (TN) was higher for samples from lowland terrains (Table 2).

\section{Morphological and yield traits of the landraces}

Morphological descriptors are widely used in defining germplasm groups and remain the only legitimate marker types accepted by the International Union for the Protection of New Varieties of Plants (UPOV) (UPOV 2002). As shown in figure 2 , there were visually distinct dissimilarities on seed shape, seed color, stem color and seedling color among the landraces. The seed of Sirinka 2017 landrace was smooth, tan round-shaped and creamy. Sirinka 2017 landrace seedlings, tillers and leaf margins were variegated green in color. Gedober 2017 landrace seed shape was round and dun-colored. Stem and seedling colors of Gedober 2017 landrace were green. The seed shape for Wemberet 2017 was smooth and variegated light red wine in color. While the stem and seedling color for Wemberet 2017 landraces was observed as light green (Figure 2).

Table 2. Soil physicochemical composition of the Abyssinian pea landraces growing terrains

\begin{tabular}{lllllll}
\hline Growing terrain & Texture & pH & ExCa & ExMg & ExNa & ExK \\
\hline Sirinka (Midland) & Clay & $7.71 \pm 0.07$ & $15.15 \pm 0.58$ & $2.71 \pm 0.14$ & $0.23 \pm 0.03$ & $0.41 \pm 0.04$ \\
Wemberet (Highland) & Loam & $7.00 \pm 0.11$ & $13.63 \pm 2.95$ & $1.99 \pm 0.26$ & $0.23 \pm 0.05$ & $0.23 \pm 0.04$ \\
Gedober (Lowland) & Clay Loam & $6.63 \pm 0.08$ & $18.77 \pm 2.05$ & $4.90 \pm 0.30$ & $0.51 \pm 0.06$ & $0.26 \pm 0.03$ \\
P<0.05 & & $0.00^{*}$ & $0.01^{*}$ & $0.01^{*}$ & 0.07 & $0.03^{*}$ \\
& & & & & \\
Growing terrains & $\mathrm{P}$ & $\mathrm{CEC}$ & $\mathrm{OM}$ & $\mathrm{SCC}$ & $\mathrm{TN}$ & $\mathrm{Mn}$ \\
Sirinka (Midland) & $2.13 \pm 0.23$ & $45.46 \pm 0.71$ & $1.09 \pm 0.12$ & $1.88 \pm 0.21$ & $0.09 \pm 0.01$ & $10.02 \pm 0.35$ \\
Wemberet (Highland) & $3.76 \pm 0.23$ & $39.73 \pm 5.01$ & $1.16 \pm 0.15$ & $1.99 \pm 0.26$ & $0.10 \pm 0.01$ & $12.73 \pm 1.31$ \\
Gedober (Lowland) & $4.23 \pm 1.99$ & $44.26 \pm 3.88$ & $1.35 \pm 0.06$ & $2.33 \pm 0.12$ & $0.12 \pm 0.01$ & $10.13 \pm 0.49$ \\
P<0.05 & 0.46 & 0.55 & 0.34 & 0.34 & 0.33 & 0.10 \\
Growing terrains & & & & & \\
Sirinka (Midland) & Cu & Zn & ExAcidity & Fe & FC & PWP \\
Wemberet (Highland) & $2.40 \pm 0.04$ & $0.45 \pm 0.10$ & $0.45 \pm 0.07$ & $5.61 \pm 0.28$ & $39.37 \pm 0.56$ & $18.89 \pm 1.46$ \\
Gedober (Lowland) & $2.61 \pm 0.12$ & $0.43 \pm 0.05$ & $0.23 \pm 0.03$ & $11.39 \pm 1.68$ & $23.58 \pm 4.63$ & $13.85 \pm 2.10$ \\
P<0.05 & $2.73 \pm 0.07$ & $0.28 \pm 0.01$ & $0.08 \pm 0.00$ & $8.01 \pm 0.48$ & $35.05 \pm 0.09$ & $20.12 \pm 0.64$ \\
& 0.07 & 0.22 & $0.03^{*}$ & $0.02^{*}$ & $0.02^{*}$ & $0.01^{*}$
\end{tabular}



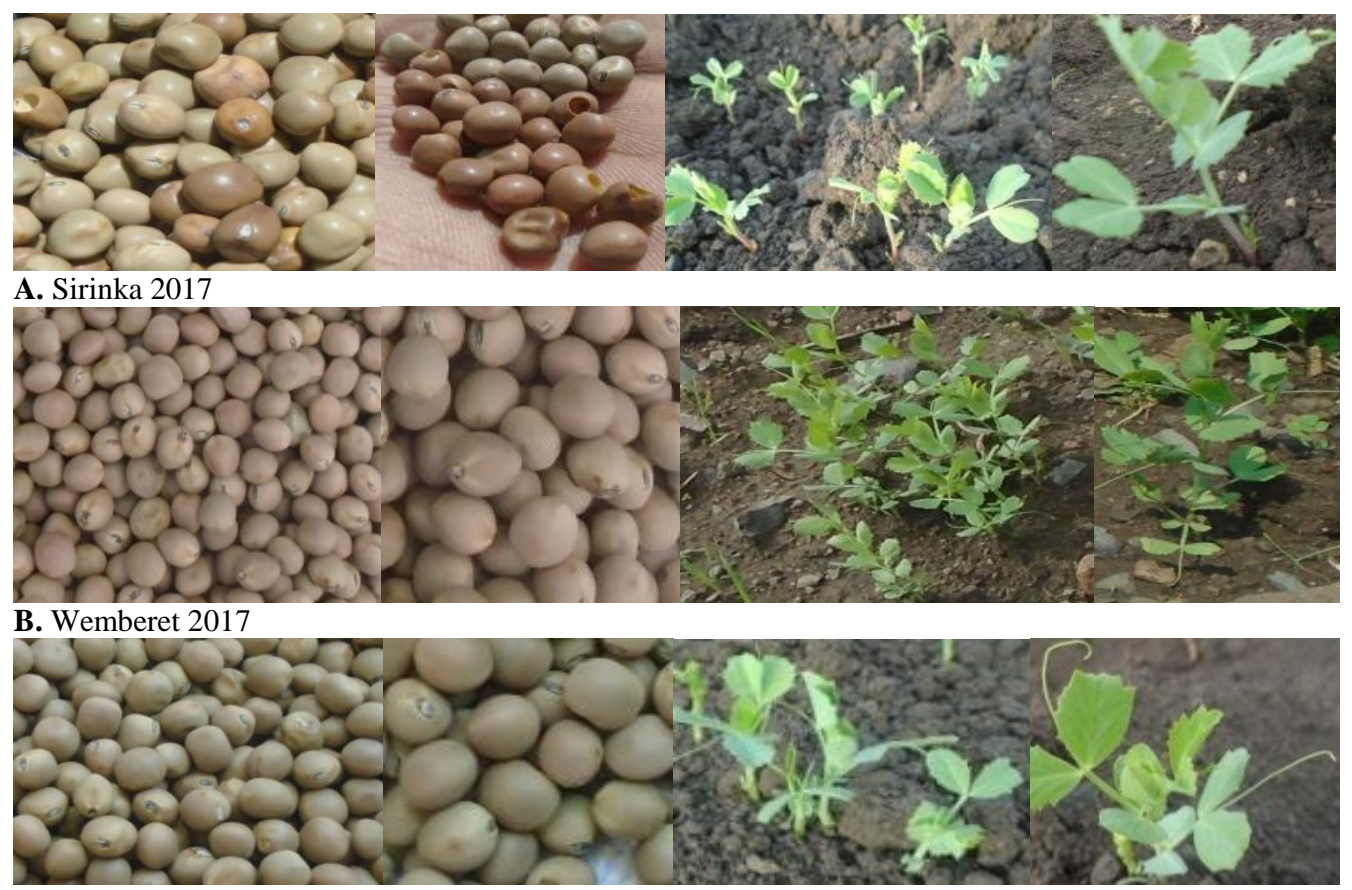

C. Gedober 2017

Figure 2. The seed and seedling color difference among the study landraces of Abyssinian pea. A. Variegated seed color of Wemberet 2017 landrace, B. Creamy seed color of Sirinka 2017 landrace, C. Dun colored seeds of Gedober 2017 landrace. For seedling color identification of the landraces, names of the landraces are given below each image.

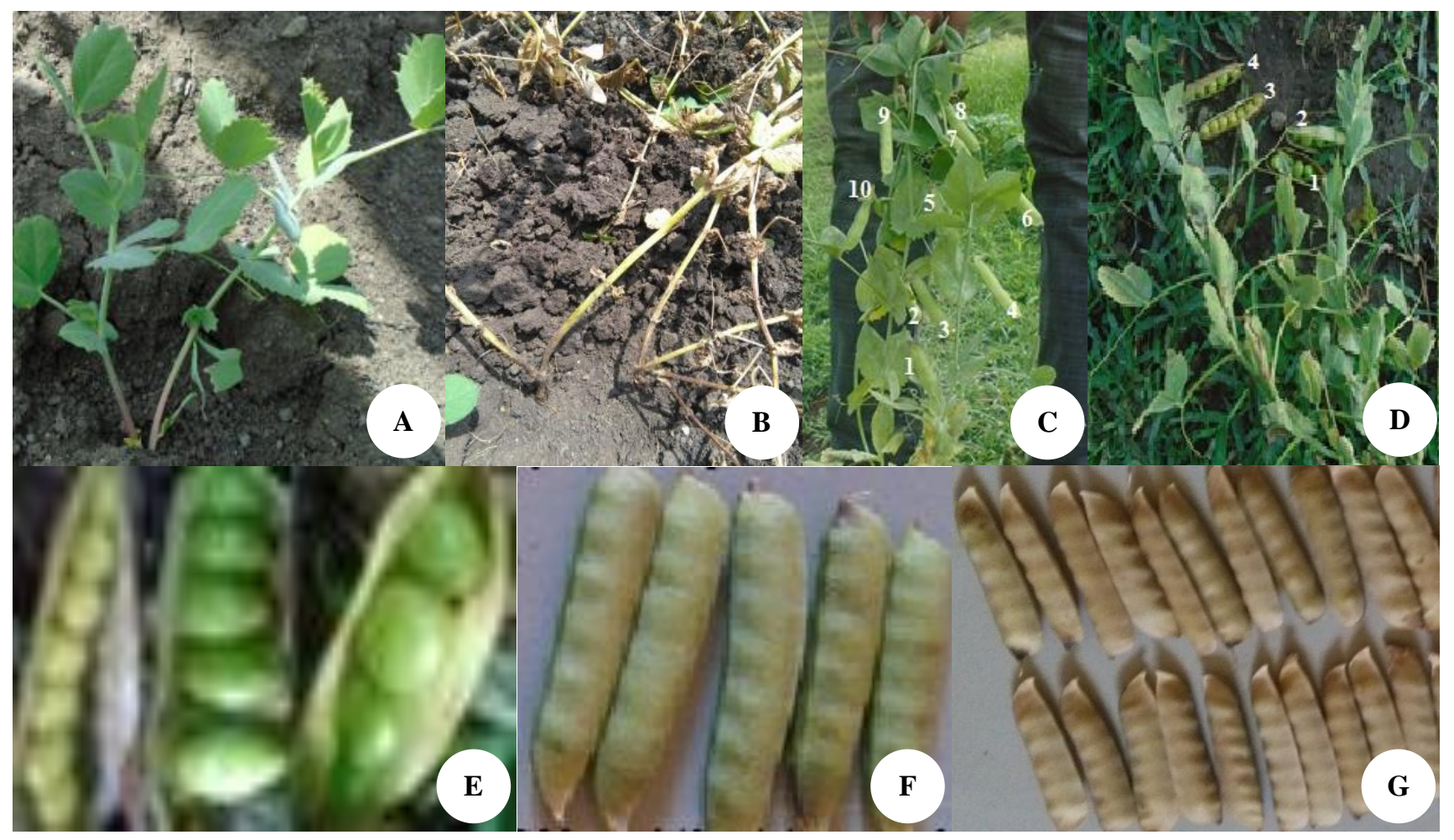

Figure 3. Morphological and yield traits of Abyssinian pea landraces recorded during the study. A. Ground-level to the tip of the main stem for Sirinka 2017 landraces. B. ground level to tip of the main stem at the time of harvest for plant height measurement and counting of numbers of tillers arising from main stem of a plant at physiological maturity stage C. Number of pods per plant D. Number of branches per plant, number of pods per plant and number of seeds per plant E. Number of seeds per pod F. Pods turned dark golden brown to yellow-green record days to maturity for seed count, G. Mature pods from the selected plants for recording seed yield per plant. 
Given the presence of the three different landraces of Abyssinian pea and three terrains, the averages of the required trait values per plant responded differently. Among the many traits evaluated viz, plant height, leaf tillers per plant, pod color and number of selected pods for seed yield (Figure 3), some differences were observed in number of pods per plant (Figures 3C and 3D) and number of seeds per pod (Figures 3D, 3E, 3F and 3G).

Morphological and yield traits of the three Abyssinian pea landraces showed inconsistency across the agroecology (Tables 3 and 4). The plant height of the Abyssinian pea landraces increased with decreasing in altitude. The maximum height was obtained from the highland crop (Wemberet 2017) gown at lowland area with plant height of $48.5 \pm 0.51$ followed by Sirinka 2017 landrace with plant height of $47.4 \pm 0.26 \mathrm{~cm}$ (Table 3 ). The lowland landrace has also number of tillers per plant than the other two landraces (Table 3). But days for $50 \%$ flowering and maturity time were comparatively longer in the highland terrain. There was a statistically significant variation even within the same landraces grown at different agroecology (Tables 3 and 4). The midland landrace (Sirinka 2017) grown at high altitude took the longest flowering time (56.00 \pm 0.04 days), while the maturity time was long (74 \pm 0.45 days) for the lowland landrace (Gedober 2017) grown at the highland terrain. When the highland landrace (Wemberet 2017) was grown at midland terrain there was an increment in plant height, number of tillers per plant and number of pods per plant though decreased in its flowering and maturity times (Table 3 ).

The analysis of variance for yield traits as affected by the type of landraces and agroecologies indicated a statistically significant variation among the landraces as well as among the agroecologies at $\mathrm{P}<0.05$ (Table 4). Landraces grown at midland terrain have more number of pods per plant than the same landraces grown at highland terrains. No difference was observed in number of pods per plant for the midland landrace (Sirinka 2017) among all the agroecologies. Number of seeds per pod of all the landraces was higher in the midland agroecology. The lowland landrace (Gedober 2017) grown at highland terrain had the highest seed number (19.72 \pm 2.00$)$ when compared with other landraces (Table 4). Gedober 2017 landrace grown at lowland and highland terrains have reduced number of seeds per pod. All the yield-related traits of the landraces were less in the lowland agroecology. Seed yield per plant, test weight, biological yield per plant and harvest index were better in the midland agroecology for all the landraces (Table 4).

Compared to the other two landraces, Gedober 2017 landrace had more number of seeds per plant where midland $>$ highland $>$ lowland $(19.72 \pm 2.00>16.53 \pm 4.12>$ $13.49 \pm 4.15$ ), respectively (Table 4 ). Seed yield per plant $(6.00 \pm 0.11 \mathrm{~g})$, test weight $(167 \pm 0.24 \mathrm{~g})$ and harvest index $(0.32 \pm 0.43)$ of Gedober 2017 landrace were found better at the midland. The biological yield $(1874 \pm 0.01 \mathrm{~g})$ of this landrace at the midland was found smaller than Sirinka 2017 and Wemberet 2017 landraces (Table 4). Seed yield per plant $(4.63 \pm 0.26 \mathrm{~g})$ and harvest index $(0.29 \pm 0.21)$ of Sirinka 2017 landraces were found better at the lowland terrain (Table 4).

\section{Discussion}

Soil physicochemical properties of the study terrains

Environmental factors influence crop growth, development and yield processes via their direct and indirect effect on soil nutrient contents (Prasad et al. 2011). Moreover, taxon/taxa bioinformatics query from generic database using passport information is becoming crucial interface returning information about rare landraces like $P$. sativum subspecies abysinicum taxonomy and geographical location which in turn means that climatic and edaphic information can be more precisely associated with genotypic and phenotypic information for a given plant under query (Lee et al. 2005).

Table 3. Univariate analysis of variance for morphological growth traits as affected by agro-ecology and Abyssinian pea landraces

\begin{tabular}{|c|c|c|c|c|c|}
\hline Agro-ecology and landraces & PH (cm) & D50\%flowering & NBPP & Maturity days & NPPP \\
\hline \multicolumn{6}{|l|}{ Highland } \\
\hline Sirinka 2017 & $35 \pm 0.26$ & $56.00 \pm 0.04$ & $13 \pm 0.58$ & $67 \pm 0.22$ & $6 \pm 0.46$ \\
\hline Wemberet 2017 & $44.5 \pm 0.62$ & $49.00 \pm 0.68$ & $12 \pm 0.14$ & $70 \pm 0.83$ & $7 \pm 0.57$ \\
\hline Gedober 2017 & $34.4 \pm 0.11$ & $50.00 \pm 1.03$ & $18 \pm 0.72$ & $74 \pm 0.45$ & $5 \pm 0.97$ \\
\hline $\mathrm{P}<0.05$ & $0.02^{*}$ & $0.03^{*}$ & $0.01^{*}$ & $0.04^{*}$ & $0.00^{*}$ \\
\hline \multicolumn{6}{|l|}{ Midland } \\
\hline Sirinka 2017 & $38.4 \pm 1.32$ & $45.22 \pm 1.03$ & $15 \pm 0.33$ & $60 \pm 0.40$ & $6 \pm 0.77$ \\
\hline Wemberet 2017 & $45.1 \pm 0.78$ & $47 \pm 0.91$ & $14 \pm 0.80$ & $66 \pm 0.55$ & $8 \pm 0.08$ \\
\hline Gedober 2017 & $44.3 \pm 0.37$ & $44 \pm 0.53$ & $18 \pm 0.15$ & $54 \pm 0.71$ & $7 \pm 0.11$ \\
\hline $\mathrm{P}<0.05$ & $0.01^{*}$ & $0.00^{*}$ & $0.00^{*}$ & $0.01^{*}$ & $0.00^{*}$ \\
\hline \multicolumn{6}{|l|}{ Lowland } \\
\hline Sirinka 2017 & $47.4 \pm 0.26$ & $37 \pm 0.03$ & $17 \pm 0.22$ & $52 \pm 0.35$ & $6 \pm 0.35$ \\
\hline Wemberet 2017 & $48.5 \pm 0.51$ & $42 \pm 1.07$ & $23 \pm 1.08$ & $61 \pm 0.56$ & $4 \pm 2.20$ \\
\hline Gedober 2017 & $46.0 \pm 0.01$ & $45 \pm 1.62$ & $20 \pm 0.14$ & $70 \pm 0.71$ & $8 \pm 0.07$ \\
\hline $\mathrm{P}<0.05$ & $0.00^{*}$ & $0.01^{*}$ & $0.00^{*}$ & $0.03^{*}$ & $0.01^{*}$ \\
\hline
\end{tabular}

Note: PH: Plant height, D50\%flowering: Days required to 50\% flowering, NBPP: Number of branches per plant, NPPP: Number of pods per plant. *: indicates significant difference 
Table 4. Univariate analysis of variance for yield traits of Abyssinian pea landraces

\begin{tabular}{|c|c|c|c|c|c|}
\hline Agro-ecology and landraces & NSPP & SYPP (g) & Test weight (g) & BYPP $(g)$ & Harvest index $(\%)$ \\
\hline \multicolumn{6}{|l|}{ Highland } \\
\hline Sirinka 2017 & $13.25 \pm 5.35$ & $4.74 \pm 0.23$ & $156 \pm 0.24$ & $1600 \pm 0.52$ & $0.29 \pm 0.11$ \\
\hline Wemberet 2017 & $14.16 \pm 3.61$ & $5.04 \pm 0.33$ & $157 \pm 0.51$ & $1781 \pm 0.71$ & $0.28 \pm 0.01$ \\
\hline Gedober 2017 & $16.53 \pm 4.12$ & $3.66 \pm 0.25$ & $154 \pm 0.42$ & $1548 \pm 0.43$ & $0.24 \pm 0.24$ \\
\hline $\mathrm{P}<0.05$ & $0.00^{*}$ & $0.00^{*}$ & $0.00^{*}$ & $0.01^{*}$ & $0.00^{*}$ \\
\hline \multicolumn{6}{|l|}{ Midland } \\
\hline Sirinka 2017 & $15.08 \pm 7.06$ & $4.98 \pm 0.12$ & $161 \pm 0.33$ & $2100 \pm 0.65$ & $0.24 \pm 0.07$ \\
\hline Wemberet 2017 & $16.00 \pm 5.39$ & $5.10 \pm 0.22$ & $164 \pm 0.21$ & $2643 \pm 0.78$ & $0.19 \pm 0.25$ \\
\hline Gedober 2017 & $19.72 \pm 2.00$ & $6.00 \pm 0.11$ & $167 \pm 0.24$ & $1874 \pm 0.01$ & $0.32 \pm 0.43$ \\
\hline $\mathrm{P}<0.05$ & $0.00^{*}$ & $0.01^{*}$ & $0.00^{*}$ & $0.00^{*}$ & $0.00^{*}$ \\
\hline \multicolumn{6}{|l|}{ Lowland } \\
\hline Sirinka 2017 & $12.5 \pm 3.68$ & $4.63 \pm 0.26$ & $149 \pm 1.22$ & $1580 \pm 0.32$ & $0.29 \pm 0.21$ \\
\hline Wemberet 2017 & $10.30 \pm 2.40$ & $3.01 \pm 0.44$ & $150 \pm 0.80$ & $1471 \pm 0.35$ & $0.20 \pm 0.24$ \\
\hline Gedober 2017 & $13.49 \pm 4.15$ & $3.49 \pm 0.27$ & $155 \pm 0.51$ & $1641 \pm 0.22$ & $0.21 \pm 0.22$ \\
\hline $\mathrm{P}<0.05$ & $0.00^{*}$ & $0.01^{*}$ & $0.00^{*}$ & $0.00^{*}$ & $0.00^{*}$ \\
\hline
\end{tabular}

A great variation was observed on the soil characteristics of the different agroecologies where Abyssinian pea landraces are grown and therefore the yield of the landraces. This could be due the wide variations in climate along with edaphic variations at differing altitude and longitude of Ethiopia (CBD 2009). The exchangeable potassium content of the loam and clay loam soils were $0.23 \pm 0.04$ and $0.26 \pm 0.03$, respectively, which is below the ranges ( 0.5 to $2.5 \%)$ of most soils stated by Jones (2003). Exchangeable potassium content of the clay soil was $0.41 \pm 0.04$, which is also below the Jones (2003) stated range. This goes with the land degradation rate, which is about 42 tons of soil per hectare per year on cultivated land in the Ethiopia highlands (Hurni 1998). Ethiopia has one of the highest rates of soil nutrient depletion in sub-Saharan Africa (Stoorvogel and Smaling 1990). Besides deterioration of the quality of the cultivated land's soil in Ethiopia is associated with the fragmentation of farm fields that cause huge impact on on-site land productivity (Tamene and Vlek 2008). The cation exchange capacity of clay soils is relevant to textural classes of soils with water pH levels below 7.0 reported by Jones (2003), because clay soils with high cation exchange capacities have high ability to hold water (https: //permaculturenews.org). These soils are considered to be more fertile, as they can hold more plant nutrients with high organic matter and increased soil pH (Sela 2018). The cation exchange capacities for the loam and clay loam soils were found to be $39.73 \pm 5.01$ and $44.26 \pm 3.88$, respectively. These were greater than the approximate cation exchange capacities reported by Jones (2003) to textural classes of loam and clay loam (21-28 and 29 - 40) soils with water $\mathrm{pH}$ levels below 7.0. The variation in cation exchange capacity of the terrain soils could be attributed to the influences of the agroecology soil type, soil $\mathrm{pH}$, soil organic matter content, soil water holding capacity, soil erodibility, farm microclimate, nutrient-use efficiency and yield factors (Tamene and Vlek 2008; Morris et al. 2016).

The studied Abyssinian pea landraces optimum soil nutrient contents requirement might differ as the landraces have different agroecological adaptation together with the differences in soil types of the three terrains. Winch (2006) working on different pea varieties found that large numbers of regional varieties of peas across the world were adapted to a wide range of growing conditions. Therefore, even the same variety of a crop can produce widely differing yields if they are grown under different soil types and climate conditions. Uchida (2000) also suggested that each plant is unique and has an optimum nutrient range as well as a minimum required level. Gedober 2017 landrace is promising in number of seeds per plant at the clay soil. It had comparatively better seed number per plant (19.72 $\pm 2.00)$. This landrace grows best at this soil type probably due to its better adaptation to soils with high water holding capacity and its nutrient use efficiency (Méndez et al. 2013; Morris et al. 2016). Similarly, the genetic study of wide crosses between cultivated pea species and the domesticated Pisum abyssinicum by Holden (2009) showed the numbers of seeds per plant were found to be different between identical accessions grown in two glasshouse environments. In support of this agroecological impact discussion, Halbeisen (2019) described that uptake and removal of nutrients by crops is relatively variable across altitudes and varied soils. The soil moisture contents were discussed referring to the common range of most soils field capacity and permanent wilting point (Figure 4). The clay soil where the promising Gedober 2017 landrace thrived on had a field capacity and permanent wilting point below the critical range where above this range plants cannot exceed to avoid the runoff and will begin to suffer.

During crop cultivation, there are many factors of which the farmer has little or certainly not control. It is indispensable to take control of the factors that can be changed (Halbeisen 2019). One of these is soil appropriate management. As described by Adams et al. (2018) the rates of biological nitrogen fixation (BNF) in agriculture remain low, with strong negative feedback to BNF from reactive soil nitrogen $(\mathrm{N})$ and drought. Grain legumes show strong relations between leaf nitrogen and water use efficiency. From the present study, the total nitrogen content was 
found higher for the lowland terrain. This could be because of the more suitability of the lowland terrain (Gedober) for the landraces. The landraces could also be good host to Rhizobium leguminosarum as it was suggested by Esen et al. (2019). This landrace showed more nodule formation when compared with the other two terrains (Gebreegziabher and Tsegay 2018).

The pHs of the soil samples for the growing terrains are classified at the neutral class soil $\mathrm{pH}$ because they were found in the ranges of soil classes classified by Buri et al. (2005). A substantial proportion of agricultural soils worldwide are currently ranging from very slightly acidic to extremely acidic (Buri et al. 2004). From all the agroecology that the landraces were cultivated in this study, the midland terrain owing to its around neutral $\mathrm{pH}$ has best overall performance (is productive). This is because soils with the peak neutrality are considered to be healthier (Halbeisen 2019) that could let the landraces to survive more vigorously through the stresses of the growing season. Similarly, Lake (2000) found that root growth increased by $40 \%$ when the $\mathrm{pH}$ of the soil increased from 5.5 to 7.2. The reason for this is that the presence of high amount of calcium in lowland terrain plays a major share in the development of young root hair tissue and cell elongation via balancing organic anions (Winch 2006). The Abyssinian pea growing terrains were not statistically different in their phosphorus composition. This might be due to the almost similar P level of the soils. Phosphorus is often deficient in tropical soils (Winch 2006). Moreover, historically crop production is stated to depend on natural soil phosphorus level if soil pH is ideal (Cordell et al. 2009).

\section{Morphological and seed yield traits of Abyssinian pea landraces}

In this study, we characterized the morphological and yield traits of three Abyssinian pea landraces in three different agroecology. This is bearing in mind that plant morphological characterization associates genomics with plant ecology and agronomy (Gatti et al. 2017). Similar to our pioneer morphological study of Abyssinian pea landraces of Ethiopia, Jha et al. (2013) reported that agronomic performance improvement and nutritional outlooks remain among the major objectives in pea breeding. But this progress requires revival of research on the centers of crop origin and crop diversity to widen the narrow gene pool available. Altitude is also identified as an important role player in the distribution of crop production in Ethiopia through its impact on rainfall, temperature, and diseases (MoANR 2016). In the lowland terrain of Ethiopia, the landraces tend to flower earlier to escape the environmental stress such as high temperature and pest damage that put crop productivity at risk, and make pest and disease outbreaks more likely to increase (CIAT 2017). Similarly, Winch (2006) reported that maturity time is affected by growth conditions such as temperature. The shorter maturity time of landraces in the lowland terrain could be as a result of the hot and dry condition that simulated the landraces to grow faster as stated by Winch (2006). Plants growing in unfavorable conditions will grow faster than plants growing in more favorable conditions. In unfavorable environments, plants need to replace themselves before they die. In this study seed and seedling features, coloration differences among the landraces were also observed. The variations of seed color among the different landraces could be due to the differences in growth conditions. A similar study stated that seed coat coloration in Abyssinian pea accessions was influenced by the presence of anthocyanin of different nature (Ellis and Poyser 2002).

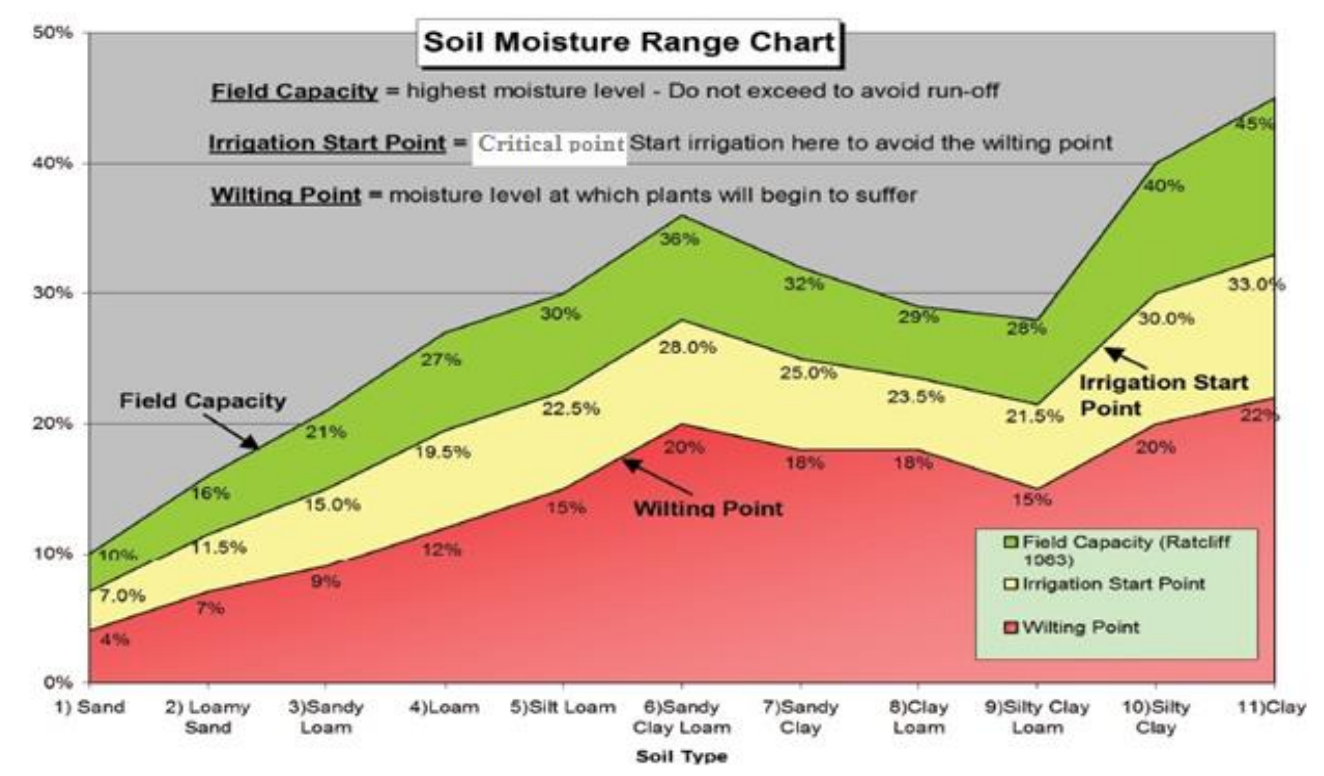

Figure 4. Soil moisture range chart expresses percentage of water by volume of different soil types. Source: www.dynamax.com 
According to the recent international report on agrobiodiversity, Ethiopia systematically reports on $84 \%$ of indicators to the World Information and Early Warning System (WIEWS) on plant genetic resources for food and agriculture, and contributed an in-depth country profile to the FAO state of the world's biodiversity for food and agriculture (FAO 2019; Bioversity International 2019). Moreover, current agrobiodiversity management in Ethiopia contributes most significantly to managing risks related to pest and diseases, through the use and conservation of varietal diversity. Therefore, promising and competent landraces like Gedober 2017 can be found from the traditional Abyssinian landraces as there are recent biodiversity report indications that superior landraces identified in Ethiopia. Coto et al. (2019) in their study on seeds for needs: crop diversity for resilience identified superior durum wheat landraces in drought-prone areas of Ethiopia, where more than $20 \%$ of the tested traditional varieties performed better than released varieties. Correspondingly, Recha et al. (2019) identified best durum wheat landraces in Ethiopia with average competent traits of $21 \%$, yield advantage of $61 \%$, and better tolerance to Sectoria tritici.

All the Abyssinian pea landraces had high seed yield ranging from $3.01 \pm 0.44-6.00 \pm 0.11 \mathrm{~g} /$ plant. The nature of optimal leaf number and leaf area of Gedober 2017 landrace cultivated at the midland terrain may cause the seed yield per plant of the landrace as highest with the maximum yield of $6.0 \mathrm{~g} / \mathrm{plant}$. Because, both fewness in leaf number and low leaf area index form highland crops causing low photosynthesis as well as presence of too much leaf where lower leaves become too shaded causing plant respiration to begin to cancel out gains from photosynthesis (Winch 2006). Similarly, Mikić et al. (2013) and Ćupina et al. (2008) demonstrated that Abyssinian pea showed high seed yield potential, with its accessions PIS 150/96 and MG 101785 producing 3.29 and $5.33 \mathrm{~g} / \mathrm{plant}$ in the agroecological conditions of Rimski Šančevi and Serbia, respectively. The reduction in seed yield of the accession studied by Ćupina et al. (2008) compared to the currently studied landraces could be discussed as practical relevance of photoperiodic effect of the seed movement from Ethiopia to Serbia that do have different latitudes and altitudinal gradients (Winch 2006). Increment in seed yield per plant was observed for all the landraces in all study terrains with increment in number of seeds and number of pods per plant of the landraces. Mikić et al. (2013) suggested that seed yield per plant of Pisum fulvum and Pisum abyssinicum is directly and highly significantly positively correlated with number of seeds per plant $(\mathrm{r}=0.937 * *)$ and number of pods per plant $(\mathrm{r}=$ $0.882 * *)$.

Even within the same altitudinal gradients of different landraces, there was inconsistency among the yield traits measured and calculated. Gedober 2017 landrace was better performer than the other two in the midland terrain even though its biological yield was smaller. At the lowland terrain, Gedober 2017 landrace was somewhat a promising one in number of seeds per plant, test weight, and biological yield. However, farmers of the midland terrain in North Wollo are not still producing this landrace. This is due to the threats of local seed supply and less cultivation practice of the Abyssinian pea in the agroecology that all farmers are not familiar and do not know the crop in the midland of North Wollo (Gebreegziabher and Tsegay 2018). Moreover, knowledge of the local farmers in particular and Ethiopian farmers in general on their diverse seeds is not context-based and their practices are not according to the agroecological principles. This needs urgent agroecological context study for the climate resilience because landraces diversity is nowadays believed to make important, though perhaps unrecognized, contributions to the ecological processes needed for agroecology to succeed (Global Alliance for the Future of Food 2016). Farmers from the lowland area are growing the landrace once in a blue moon after teff harvest. Others from the midland terrain grow Sirinka 2017 landrace at the brink of stable crops with soil that is worn and less fertile during the long rainy season. In South Tigray, Wemberet 2017 landrace is nowadays cultivated both during the long rainy season, using the short rain from spring, and via irrigation (Personal observation).

The low productivity of all the landraces in general and Wemberet 2017 landrace in particular in lowland terrain was possible because of agroecological unsuitability. This is because peas are known to produce low yield and/or do not thrive in high temperatures or lowland tropical climates (Zaki et al. 2016). This problem is mainly severe in northern Ethiopia where productivity is limited by drought and infertile soils. Likewise, Thiaw et al. (1993) specified that crop productivity is low and variable under rain fed conditions in semiarid zones. The harvest index of Gedober 2017 landrace grown in midland altitude was found to be comparable with the average harvest index $(0.32 \pm 0.43)$ of other grain legumes (such as lupine, field pea, faba bean, lentil, chickpea, and vetch) which all having 0.37 harvest index (Unkovich et al. 2010). The harvest index of Sirinka 2017 landrace grown in highland and midland altitudinal terrains was higher next to Gedober 2017 landrace. Beyond the altitudinal gradients across agroecology, soil factors such as textural class, exchangeable bases like exchangeable sodium are suggested to affect the overall performances of the landrace thereby bring difference in their overall yield. Therefore, transforming farmers based on Ethiopia's agriculture is an urgent priority by encouraging specialists to undertake studies on agroecology as suggested for Africa's agriculture transformation priority requirement by Mugwanya (2019).

It can be concluded that altitudinal gradients and soil quality factors brought a statistically significant difference among the Abyssinian pea landraces. Even the same landrace grown in different agroecology have different phenotypic performances. Midland is good agroecology for vigorousness and overall better yield of Abyssinian pea landraces. Highland grown landraces are less vigorous and shorter in plant height. Lowland terrain grown landraces are taller in height than the other agroecologies. Overall performance of landraces was lower in the lower altitude 
due to the impacts from the altitudinal gradients and soil factors. Gedober 2017 landrace performs best in seed yield per plant and harvest index traits in mid-altitude. Generally, overall performance variations of the landraces depend on the interactive effects of altitudinal gradients and soil properties of the agroecology. Therefore, from this study, it can be recommended that the Abyssinian pea landraces could be cultivated and maintained under field conditions based on agroecological requirements screening. This should consider the landraces cultivation season, lifespan, altitudinal gradient and the soil factors for yield improvement. Gedober 2017 is recommended as a promising landrace that needs future growers' attention to expand and adapt to the midland and highland pea production potential areas of Ethiopia.

\section{ACKNOWLEDGEMENTS}

The authors acknowledge the Ethiopian Ministry of Higher Education for providing financial support. Science College of Bahir Dar University is also greatly acknowledged for its financial support under its grant number BDU/RCS/Sc 02/2010. We would like to thank the farmers, agricultural experts and development agents, and local administrators for their assistance during the fieldwork, and the authors declare that they have no conflicts of interest.

\section{REFERENCES}

Adams MA, Buchman N, Sprent J, Buckley TN, Turnbull TL. 2018. Crops, nitrogen, water: are legumes friend, foe, or misunderstood ally? Trends Plant Sci 23: 539-550.

Agegnehu G. 2018. Soil fertility and crop management research on coolseason food legumes in the Central Highlands of Ethiopia. Ethiop J Agric Sci 28: 95-109.

AOAC. 1960. Official Methods of Analysis. 10 $0^{\text {th }}$ ed. Association of Official Analytical Chemists, Washington DC.

Berg T. 2009. Landraces and folk varieties: a conceptual reappraisal of terminology. Euphytica 166: 423-430.

Bioversity International. 2019. Agrobiodiversity Index Report 2019: Risk and Resilience. Rome (Italy): Bioversity International. https: //hdl.handle.net/10568/100820.

Buri MM, Issaka RN, Wakatsuki T. 2005. Extent and management of low ph soils in Ghana. Soil Sci Plant Nutr 51: 755-759.

Buri MM, Issaka RN, Wakatsuki T, Otoo E. 2004. Soil organic amendments and mineral fertilizers: options for sustainable lowland rice production in the forest agroecology of Ghana. Agric Food Sci J Ghana 3: 237-248.

CIAT. 2017. CIAT in Ethiopia: Science for Impact. Building a sustainable food future since 1967. CIAT 1967-2017, CGIAR Research Center.

Convention on Biological Diversity (CBD). 2009. Ethiopia's $4^{\text {th }}$ Country Report to the CBD. Institute of Biodiversity Conservation. Addis Ababa, Ethiopia, November 2009

Cordell D, Drangert J, White S. 2009. The story of phosphorus: Global food security and food for thought. Glob Environ Change 19: 292 305.

Coto A, de Sousa K, Fadda C, Gebrehawaryat Y, van de Gevel J, Gotor E, Gupta A, Madriz B, Mathur P, Mengistu DK, Paliwal A, Quirós CF, Scafetti F, Sharma N, Steinke J, van Etten J. 2019. Seeds for Needs: crop diversity for resilience. Poster and handout presented at the $2^{\text {nd }}$ Meeting of the Joint Boards of Bioversity International and CIAT. Maccarese, Rome, Italy, Bioversity International, May 2019. [Italy].
CSA (Central Statistical Agency). 2013. Ethiopia rural socioeconomic survey (ERSS). Central statistical agency and the World Bank, May $7^{\text {th }}, 2013$.

Ćupina B, Mihailović V, Mikic' A, Erić P, Krstić Đ. 2008. Evaluation of seed yield components in Ethiopian pea (Pisum sativum subsp. abyssinicum (A. Braun) Govorov). In: Annicchiarico P, Bochard AM, Ellis N, Mikić A, Ramos Monreal Á, Smýkal P, Warkentin T, Winter P (eds) Book of Abstracts of the Second Grain Legumes Technology Transfer Platform (GL-TTP) Workshop, Institute of Field and Vegetable Crops, Novi Sad-GL-TTP, Paris.

Difalco S, Chavas JP. 2009. On crop biodiversity, risk exposure, and food security in the highlands of Ethiopia. Amer J Agr Econ 91: 599-611.

Donald CM. 1962. In search of yield. No. REP-10660. CIMMYT.

Ellis THN, Poyser SJ. 2002. Research review: An integrated and comparative view of pea genetic and cytogenetic maps. New Phytol 153: $17-25$.

Esen A, Sari H, Erler F, Adak A, Sari D, Eker T, Canci H, İkten C, Kahraman A, Toker C. 2019. Screening and selection of accessions in the genus Pisum L. for resistance to pulse beetle (Callosobruchus chinensis L.). Euphytica 215: 82.

FAO. 2019.The State of Ethiopia's Biodiversity. Food and Agriculture Organization, Rome.

FAO. 2012. Economics of plant genetic resource management for adaptation to climate change. ESA Working paper No. 12-02 FAO. 2010. The second report on the state of the World's plant genetic resources for food and agriculture, FAO, Rome.

Gatti I, Guindón MF, Bermejo C, Cointr EL. 2017. Analysis of variability and phylogeny in Pisum (Pisum spp.) using digital phenotyping and morphological traits. AJCS 11(12):1599-1605.

Gebreegziabher BG, Tsegay BA. 2018. Evaluation of farmers' knowledge on the rare Abyssinian pea (Pisum sativum var. abyssinicum) landraces of Ethiopia. Biodiversitas 19: 1851-1865.

Gebreegziabher BG, Tsegay BA. 2017. Adaptability of Dekoko (Pisum sativum var. abyssinicum) seedlings to salinity stress in vitro culture conditions. J Bios Agric Res 12: 1054-1064.

Gebreslassie B, Abraha B. 2016. Review: Distribution and productivity of dekoko (Pisum sativum var. abyssinicum A. Braun) in Ethiopia. Glob J Sci Front Res C Biol Sci 16: 45-57.

Gibson AH, Dreyfus BL, Dommergues YR. 1982. Nitrogen fixation by legumes in the tropics. In: Dommergues YR and Diem HG (eds) Microbiology of Tropical Soils and Plant Productivity. Martinez Nijhoff/Dr. W. Junk Publishers, Hague, Holanda.

Global Alliance for the Future of Food. 2016. The Future of Food: Seeds of Resilience, A Compendium of Perspectives on Agricultural Biodiversity from Around the World.

Halbeisen J. 2019. Nutrient Recommendations. Growers Mineral Solutions. Accessed from ht //www.growersmineral.com/crops/indepth-articles/out-of-datenutrient-recommendations. Retrieved 19 March 2019.

Hedrick UP. 1928. The Vegetables of New York. Report of the New York state agricultural experiment station for the year ending. Geneva, New York, 30 June 1928.

Herweg K, Stillhardt B. 1999. The variability of soil erosion in the highlands of Ethiopia and Eritrea. Average and extreme erosion patterns. Research Report 42, Soil Conservation Research Programme, Addis Ababa.

Holden D. 2009. Genetic studies of wide crosses between cultivated pea species, and the domestication of Pisum abyssinicum. [Dissertation]. School of Biological Sciences, University of East Anglia, Colworth, UK.

Hue N, Uchida VR, Ho MC. 2004. Testing Your Soil: Why and How to Take a Soil-Test Sample. Department of Agronomy and Soil Sciences, College of Tropical Agriculture and Human Resources (CTAHR), University of Hawaii.

Hue N, Uchida VR, Ho MC. 1997. Testing Your Soil: Why and How to Take a Soil-Test Sample. Department of Agronomy and Soil Sciences, College of Tropical Agriculture and Human Resources (CTAHR), University of Hawaii, Honolulu.

Hurni H. 1998. Degradation and conservation of resources in the Ethiopian highlands. Mt Res Dev 8(2/3): 123-130.

IUSS Working Group WRB. 2015. World reference base for soil resources 2014, update 2015 international soil classification system for naming soils and creating legends for soil maps. World Soil Resources Reports No. 106. FAO. Rome.

Jha AB, Arganosa G, Tarán B, Diederichsen A, Warkentin TD. 2013. Characterization of 169 diverse pea germplasm accessions for 
agronomic performance, Mycosphaerella blight resistance and nutritional profile. Genet Resour Crop Evol 60: 747-761.

Jones JB. 2003. Agronomic Handbook: management of crops, soils, and their fertility. CRC Press, Boca Raton, FL.

Lake B. 2000. Understanding soil pH. Acid Soil Action. Leaflet number 2. Yanco Agricultural Institute, Australia.

Lee JM, Davenport GF, Marshal D, Ellis THN, Ambrose MJ, Dicks J, van Hintum TJL, Flavell AJ. 2005. GERMINATE. A generic database for integrating genotypic and phenotypic information for plant genetic resource collections ${ }^{1[\mathrm{w}]}$. Plant Physiol 139: 619-631.

Meles K, Nigussie G, Belay T, Manjur K. 2009. Seed system impact on farmers' income and crop biodiversity in the drylands of southern Tigray. DCG Report 54: 1-76.

Méndez VE, Bacon CM, Cohen R. 2013. Agroecology as a transdisciplinary, participatory, and action-oriented approach. Agroecol Sustain Food 37 (1): 3-18.

Mikić A, Mihailović V, Dimitrijević M, Petrović S, Ćupina B, Đorđević V, Kosev V, Milošević B, Jovanović Ž, Milovac Ž. 2013. Evaluation of seed yield and seed yield components in red-yellow (Pisum fulvum) and Ethiopian (Pisum abyssinicum) peas. Genet Resour Crop Evol 60: 629-638.

Ministry of Agriculture and Natural Resources (MoANR). 2016. Plant Variety Release, Protection and Seed Quality Control Directorate of Addis Ababa, Ethiopia. Crop Variety Register 19: 100-101

Morris KS, Méndez VE, van Zonneveld M, Gerlicz A, Caswell M. 2016. Agroecology and climate change resilience in smallholder coffee agroecosystems of Central America. ARLGResearch Brief \#4. Agroecology and Rural Livelihoods Group (ARLG), University of Vermont, Burlington, VT.

Mugwanya N. 2019. Why agroecology is a dead-end for Africa. Outlook on Agriculture 48: 113-116.

NCR-13 Soil Testing and Plant Analysis Committee. 2011 Recommended chemical soil test procedures for the North Central Region. North Central Regional, Research Publication No. 221.

Olsen SR, Cole C, Watanabe FSV, Dean LA. 1954. Estimation of Available Phosphorus in Soils by Extraction with Sodium Bicarbonate. U.S. Department of Agriculture Circular No. 939.

Pal DK, Mandal DK, Bhattacharyya T, Mandal C, Sarkar D. 2009. Revisiting the agro-ecological zones for crop evaluation. Indian J Hum Genet 69: 315-318.

Prasad PVV, Pisipati SR, Momčilovic' I, Ristic Z. 2011. Independent and combined effects of high temperature and drought stress during grain filling on plant yield and chloroplast EF-Tu expression in spring wheat. J Agron Crop Sci 197: 430-441.

Recha T, Muwanika C, De Jonge B, Mulumba W, Nankya R, Otieno G. 2019. Report of the International Workshop on Registration of
Farmers' Varieties, 4-7 December 2018, Entebbe, Uganda. Bioversity International, Rome, Italy.

Sela G. 2019. Cation exchange capacity of soils. Smart fertilizer management. 2018. Accessed from https: //www.smart-fertilizer.com. Retrieved on 4 September 2018.

Sharma S. 2019. Comparing soil test kits with standard lab-based soil tests for agricultural soils. Crops Soils Mag 52: 18-20.

Smýkal P, Coyne C, Redden R, Maxted N. 2013. Peas. In: Singh M, Upadhyaya HD, Bisht IS (eds.). Genetic and Genomic Resources of Grain Legume Improvement. Birmingham, UK.

Snapp S, Rahmanian M, Batello C. 2018. Pulse crops for sustainable farms in sub-Saharan Africa. FAO, Rome.

Stoorvogel J, Smaling EMA. 1990. Assessment of soil nutrient depletion in Sub-Saharan Africa: 1983-2000. Report No. 28, Wageningen, The Netherlands.

Tamene L, Vlek PLG. 2008. Soil erosion studies in Northern Ethiopia. In: Braumoh AK, Vlek PLG. (eds). Land Use and Soil Resources. Springer, Dordrecht.

Thiaw S, Hall AE, Parker DR. 1993. Varietal intercropping and the yields and stability of cowpea production in semiarid Senegal. Field Crops Res 33: 217-233.

Thom WO, Schwab GJ, Murdock LW, Sikora FJ. 2003. AGR-16: Taking Soil Test Samples. Director of Cooperative Extension Service, University of Kentucky, Lexington, KY.

Uchida R. 2000. Essential Nutrients for Plant Growth: Nutrient Functions and Deficiency Symptoms. In: Silva J. A. and Uchida R. (eds). Plant Nutrient Management in Hawaii's Soils, Approaches for Tropical and Subtropical Agriculture. Chapter 3, pp. 31-55. College of Tropical Agriculture and Human Resources, University of Hawaii at Manoa.

Unkovich M, Baldock J, Forbes M. 2010. Variability in harvest index of grain crops and potential significance for carbon accounting: examples from Australian agriculture. Adv Agron 105: 173-219.

UPOV-BMT: BMT/36/10. 2002. Progress report of the $36^{\text {th }}$ session of the technical committee, the technical working parties and working group on biochemical and molecular techniques and DNA profiling in particular. Geneva, Switzerland.

Vavilov NI. 1951. The origin, variation, immunity and breeding of cultivated plants. Chronica Botanica 13: 1-364.

Winch T. 2006. Growing Food: A guide to food production. https: //epdf.pub/growing-food-a-guide-to-food-production.html.

Zaki EMH, Mahmoud MMA, Abd El-Ati1 YY, Hammad MA, Sayed MMR. 2016. Studies on pea (Pisum sativum L.) growth and productivity under agroforestry system: 2 . Yield and seed quality of pea under alley cropping system with two types of trees. J Basic Appl Res 3: 1-9. 